образовании / Д. И. Иванов // Воспитание. Образование. Педагогика. - 2007. - №6 (12). 32 с. 8. Національній стратегії розвитку освіти в Україні на період до 2021 року [Електронний ресурс]. - Режим доступу: http://president.gov.ua/ documents/15828.html. 9. Хуторской А. В. Ключевые компетенции как компонент личностно-ориентированной парадигмы / А. В. Хуторской // Народное образование. 2003. - № 2. - C. 58-64. 10. Term Glossary of the Labor Market, Development of the Educational Program Standards and Educational Plans. [Текст]/- Европейский фонд образования: ЕФО, 1997. - С. 69-70.

Наталія Белікова

\title{
КОНЦЕПТУАЛЬНІ ОСНОВИ ПРОФЕСІЙНОЇ ПІДГОТОВКИ МАЙБУТНІХ УЧИТЕЛІВ ФІЗИЧНОЇ КУЛЬТУРИ
}

Бєлікова Н. О. Концептуальні основи професійної підготовки майбутніх учителів фізичної культури.

Визначено та науково обгрунтовано концептуальні основи професійної підготовки майбутніх учителів фізичної культури: взаємопов'язані властивості (релевантність професійному середовищу, інноваційність, комунікативність, трансформованість, комфортність, демократизація і випереджувальний розвиток), принципи та етапи цього процесу.

Ключові слова: професійна підготовка, властивості, принципи, етапи, майбутній учитель фізичної культури.

Беликова Н. А. Концептуальные основы профессиональной подготовки будущих учителей физической культуры.

Определены и научно обоснованы концептуальные основы профессиональной подготовки будущих учителей физической культуры: взаимосвязанные свойства (релевантность профессиональной среде, инновационность, коммуникативность, трансформированность, комфортность, демократизация и опережающее развитие), принципы и этапы этого процесса.

Ключевые слова: профессиональная подготовка, свойства, принципы, этапы, будущий учитель физической культуры. teachers.

Belikova N. O. Professional training conceptual foundations of future physical education

Such conceptual framework of future physical education teachers' training as intertwined properties (professional environment relevancy, innovation, communicativeness, transformation, comfort, democratization and predevelopment), principles and stages of this process has been defined and scientifically grounded.

Key words: professional training, properties, principles, stages, future physical education teacher.

На сучасному етапі розвитку професійної вищої школи основною ідеєю концепції вищої освіти є підготовка висококваліфікованого фахівця, конкурентноздатного на ринку праці, який вільно володіє своєю професією й орієнтується в суміжних галузях діяльності, здатного до ефективної роботи зі спеціальності на рівні світових стандартів, готового до постійного професійного зростання, соціальної і професійної мобільності. 
Високі вимоги, які висуває сучасне суспільство до вчителя фізичної культури, починаючи від необхідності неперервно підвищувати професійну кваліфікацію і закінчуючи необхідністю виявляти творчий підхід до професійної діяльності, неможливо реалізувати без використання в системі вищої фізкультурної освіти принципів і методів, які здатні забезпечити та підтримати процеси самопізнання й самоконструювання особистості фахівця.

Фундаментальну основу професійної підготовки майбутніх учителів фізичної культури заклали дослідження Е. Вільчковського, М. Данилка, О. Демінського, М. Дутчака, О. Смця, Р. Карп’юка, Р. Клопова， А. Коноха， О. Куца， С. Приступи, Т. Ротерс, Л. Сущенко, О. Тимошенко, А. Фурмана, Б. Шияна, Ю. Шкребтія та ін.

Водночас актуальним $\epsilon$ дослідження концептуальних основ професійної підготовки майбутніх учителів фізичної культури з урахуванням сучасних тенденцій вищої фізкультурної освіти.

Мета статті - визначити та обгрунтувати концептуальні основи професійної підготовки майбутніх учителів фізичної культури через систему властивостей, принципів та етапів цього процесу.

В основу концепції професійної підготовки майбутніх учителів фізичної культури покладено прогностичні ідеї, використані в Національній доктрині розвитку освіти (2001), Національній доктрині розвитку фізичної культури і спорту (2004), Законі України «Про фізичну культуру і спорт» (1994), Державній програмі розвитку фізичної культури і спорту на 2007-2011 роки (2006), Концепції Загальнодержавної цільової соціальної програми розвитку фізичної культури і спорту на 2012-2016 роки (2011), Концепції Загальнодержавної програми «Здоров’я 2020: український вимір» на 20122020 pp. (2011), які є системою орієнтирів і поглядів на роль, організацію та функціонування сфери фізичної культури і спорту в Україні на довгостроковий період 3 урахуванням розвитку держави та світового досвіду.

До властивостей професійної підготовки майбутніх учителів фізичної культури ми відносимо релевантність професійному середовищу, інноваційність, комунікативність, трансформованість, комфортність, демократизацію, випереджувальний розвиток (рис. 1). Розкриємо їх зміст.

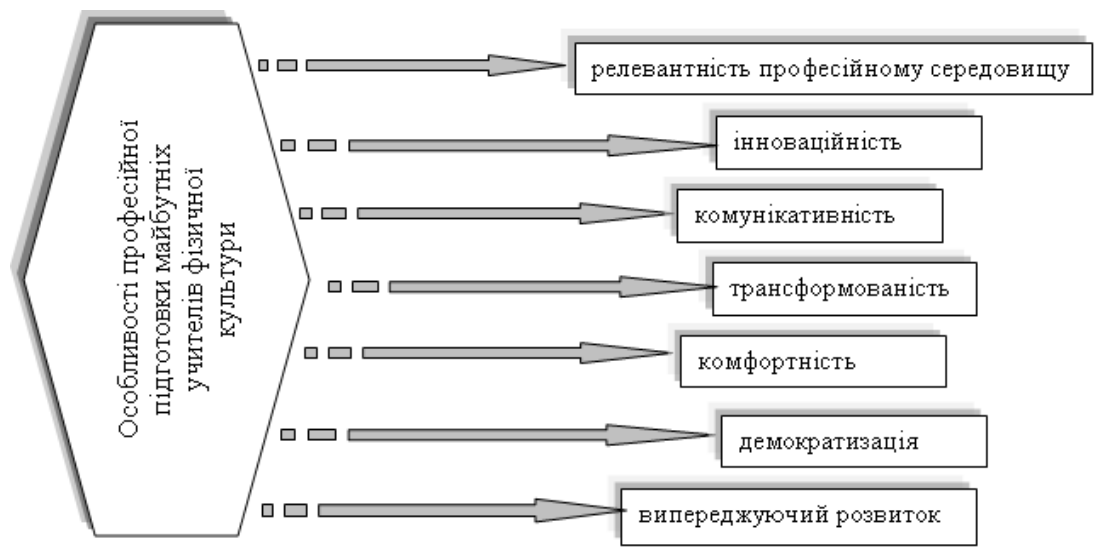

Рис. 1. Властивості професійної підготовки майбутніх учителів фізичної культури 
1. Релевантність професійному середовищу здійснюється через використання в навчальному процесі професійної підготовки майбутніх учителів фізичної культури професійно значущих засобів і ресурсів.

2. Інноваційність реалізується впровадженням у навчальний процес професійної підготовки майбутніх учителів фізичної культури сучасних наукових досліджень, а також технологій, методів, форм та інструментаріїв.

3. Комунікативність забезпечується спілкуванням майбутніх учителів фізичної культури 3 науковими працівниками, педагогами, спеціалістами-практиками в галузі фізичної культури.

4. Трансформованість, тобто можливість зміни змістового наповнення компонентів навчально-практичного середовища професійної підготовки майбутніх учителів фізичної культури з орієнтацією на інновації у професійній діяльності.

5. Комфортність передбачає створення сприятливих умов для навчання майбутніх учителів фізичної культури, які сприяють формуванню позитивної мотиваційної основи у професійній діяльності.

6. Демократизачія визначається як створення рівних можливостей, відкритості, умов для самоорганізації, самоуправління процесом підготовки майбутніх учителів фізичної культури.

7. Випереджувальний розвиток розглядається як забезпечення майбутніх учителів фізичної культури рівнем підготовки й розвитку особистості, який повинен випереджувати рівень розвитку сучасних фізкультурно-оздоровчих та педагогічних технологій.

Нами визначено такі принципи професійної підготовки майбутніх учителів фізичної культури: суб'єктності, неперервності, гуманізації, інтеграції, відкритості й динамічності, науковості, міждисциплінарності, індивідуалізації, проблемності, інноваційності, інтерактивності, креативності, самостійності і рефлективності.

Принщип суб’ єктності, який є методологічним у професійній підготовці майбутніх учителів фізичної культури, вимагає орієнтації всієї педагогічної системи на створення умов для розвитку професійної компетентності майбутніх учителів фізичної культури і творчої самореалізації особистості. Така цільова настанова повинна бути домінуючою під час розроблення освітніх програм, навчальних планів, вибору технологій навчальнопрофесійної діяльності. У професійній діяльності майбутніх учителів фізичної культури суб'єктність - це показник цілісності особистості, іiі здатність самостійно приймати рішення в конкретних професійних ситуаціях, брати на себе відповідальність за результат власної педагогічної діяльності. Відповідно, зміст підготовки майбутніх учителів фізичної культури повинен бути сконструйованим так, щоб створити умови для самостійного вибору, індивідуального просування і самооцінки результату у професійній педагогічній діяльності. Одним із можливих варіантів реалізації цього принципу є самостійна професійна діяльність студента, якою у процесі навчання може бути практика (навчальна, педагогічна, виробнича). Вона надає змогу студенту відчути себе дійсним суб'єктом свого професійного становлення в умовах професійноособистісного процесу навчання. Професійна практико-орієнтована діяльність повинна відповідати таким умовам: бути змістовно насиченою, вимагаючи інтелектуального й емоційного напруження; бути самокерованою, допускаючи варіативність у засобах досягнення кінцевого результату.

Приниии неперервності реалізується через забезпечення неперервності й послідовності професійної підготовки майбутніх учителів фізичної культури, від адаптивного й креативного рівня до рівня стійкого саморозвитку, який забезпечується поєднанням різних організаційних форм навчання з самоосвітою. 
Варто зауважити, що сучасна освіта вимагає перманентного поповнення знань, що не закінчується 3 отриманням диплома про вищу освіту. Темпи розвитку соціуму, інтереси людей, потреби, що постійно змінюються, створюють передумови для майбутніх учителів фізичної культури опановувати все нові знання, новітні педагогічні та оздоровчі технології. Звідси постає проблема неперервної професійної освіти, яка означає не тільки освіту впродовж всього життя, а й передбачає постійний перехід на більш високі рівні, якісний і кількісний прогрес фахівця в оперуванні своїми професійними знаннями і вміннями, набуття життєвого і професійного досвіду.

В. Буштрук, Ю. Войнар, В. Костюченко й Е. Шубін уважають, що неперервна освіта неможлива без процесу формування інформаційної культури майбутнього фахівця [1, с. 35]. Сучасний ринок праці диктує необхідність постійного підвищення кваліфікації, оновлення професійних знань. До розв'язання цього завдання готові лише фахівці, що вміють здобувати нову інформацію й ефективно іiі використовувати в педагогічній і управлінській діяльності.

Головний сенс неперервної вищої фізкультурної освіти- постійне творче оновлення, розвиток і вдосконалення кожної людини, ії особистих, фізичних якостей і зміцнення здоров'я впродовж усього іiі життя, що зумовлює і процвітання всього суспільства. Зростання ролі неперервної фізкультурної освіти в сучасній соціальноекономічній ситуації, як уважає В. Мартиненко, приводить до того, що «поряд 3 традиційними функціями педагога (навчання, виховання, допомога в розвитку, оцінка, робота з батьками тощо) в умовах модернізації освіти актуалізуються також професійні функції: організація змістовного і професійного аспектів освіти й соціокультурного середовища» $[2$, с. 56]. На думку автора, «основним є розв’язання завдань посилення адресної підготовки фахівців, максимальної орієнтації на конкретні запити освітніх установ усіх типів і рівнів акредитації й суб' єктів ринку освітніх послуг, збережених для свободи вибору особою освітньої траєкторії» [2, с. 57].

У нашому дослідженні принцип неперервності реалізується в часовому i просторовому взаємозв'язку етапів і ступенів навчання, на яких проходить професійна підготовка майбутніх учителів фізичної культури через послідовне, поступове засвоєння нових знань, умінь і навичок, формування професійно важливих якостей.

Принции гуманізації реалізується через створення максимально сприятливих умов для розвитку демократизму міжособистісних відносин між студентами і викладачами, спрямування навчально-виховного процесу на формування в майбутніх учителів фізичної культури багатопланової, цілісної й динамічної картини духовного розвитку людства, розуміння сутності гуманістичних відносин, створення умов для розвитку високих соціальних, моральних, інтелектуальних та фізичних якостей для забезпечення внутрішніх потреб у реалізації творчих можливостей особистості студента.

Принции інтегращіï вимагає створення у вищому навчальному закладі єдиного, взаємопов'язаного за змістом, структурою, функціональними характеристиками цілісного процесу професійної підготовки майбутніх учителів фізичної культури. Принцип інтеграції реалізується через організацію цього процесу на основі міжпредметності й комплексності з використанням потенціалу професійно орієнтованих дисциплін та практичної підготовки студентів.

Приниии відкритості і динамічності реалізується через забезпечення адекватності й релевантності професійно орієнтованого освітнього середовища вищого навчального закладу цільовим настановам професійної підготовки майбутніх учителів фізичної культури та запитам професійного середовища.

Принцип науковості передбачає наявність у майбутніх учителів фізичної культури знань основних теоретичних положень, понятійного апарату, методів і способів, 
закономірностей і властивостей здійснення професійно-педагогічної діяльності, яка $є$ предметною сферою їх підготовки; дотримання службового етикету у професійному спілкуванні й уміння грамотно виконувати професійні обов'язки.

Принцип міждисциплінарності передбачає інтегративний вплив спеціальних дисциплін (сукупності міжпредметних зв'язків), які зумовлюють формування системи знань, умінь і навичок та професійно важливих якостей студента i ̈̈х використання у практичній педагогічній діяльності. Метою міжпредметних зв'язків $є$ формування культури здоров'я та спрямованості на фізкультурно-оздоровчу діяльність майбутнього вчителя фізичної культури.

Принцип індивідуалізащії реалізується через створення сприятливих умов для розкриття й розвитку потенціалу майбутнього вчителя фізичної культури. Логічно це стає можливим за умови розроблення творчих завдань, які враховують індивідуальні якості особистості. Залучити студентів до наукової творчості дозволяють спецкурси, спецсемінари, робота над професійними проектами.

Принцип проблемності передбачає створення проблемних ситуацій професійної спрямованості у процесі професійної підготовки майбутніх учителів фізичної культури, для розв'язання яких необхідне використання комплексу професійно орієнтованих i спеціальних знань, умінь та навичок.

Принцип інноваційності реалізовується через варіативність та динамічність змісту, форм, методів і технологій підготовки майбутніх учителів фізичної культури, спрямованих на формування можливості і здатності студентів до творчого перетворення соціальної дійсності, проектування, організації та здійснення фізкультурно-оздоровчої діяльності, яка передбачає інваріативність розв'язання професійних завдань, багатокритеріальність контролю й оцінки досягнутих результатів.

Принции інтерактивності розуміється як взаємодія суб'єктів професійного навчання за допомогою безпосереднього контакту, тобто можливість навчатися у процесі діалогу з усіма учасниками освітнього процесу засобами спеціалізованого освітнього інформаційного середовища (наприклад, комп’ютерне спілкування).

Принции креативності передбачає розкриття індивідуальності кожного студента, розвиток творчого й комунікативного потенціалу особистості, формування в майбутніх учителів фізичної культури умінь оперативно знаходити й ефективно застосовувати нестандартні, оригінальні творчі вирішення ситуацій міжособистісної професійної взаємодії, формування здатності самостійного вибору форм і засобів виконання завдань у професійно-педагогічній діяльності.

Приниип самостійності передбачає самостійне набуття студентами нових професійно орієнтованих знань та способів діяльності, зокрема й із використанням інформаційних технологій, необхідних для теоретичної i практичної готовності майбутніх учителів фізичної культури до професійно-педагогічної діяльності.

Принции рефлексивності відображає актуалізацію процесів самооцінки, самовизначення й самореалізації майбутніх учителів фізичної культури використанням проблемно-нестандартних професійних ситуацій. Цей принцип передбачає усвідомлення студентами змісту і способів фізкультурно-оздоровчої діяльності, а головне - власних особистісних змін, які виникають у процесі послідовного засвоєння все більш абстрактних фрагментів професійного простору, охоплюючи теоретичний i методологічний рівні рефлексії у професійній діяльності.

Ми дотримуємося позиції, що процес професійної підготовки майбутніх учителів фізичної культури охоплює такі послідовні етапи: адаптація, диференціація, індивідуалізація та стійкий саморозвиток. 
Стадія адаптаціï характеризується формуванням самосвідомості, самооцінки й самоуправління студента; становленням уявлення про себе як про фахівця; невизначеністю уявлення про способи професійної діяльності; виникненням труднощів у самоорганізації; актуалізацією інтересу до предметів професійно орієнтованого циклу; розвитком здібностей до професійної інтерпретації життєвих ситуацій.

Стадія диферениіації характеризується виявом індивідуальної неповторності, яка визначається розвитком таких якостей, як рефлексивність, креативність, критичність; прагненням поповнити знання про себе як майбутнього професіонала; формуванням навичок саморегуляції навчально-практичної діяльності.

Стадія індивідуалізації характеризується сформованою самосвідомістю, адекватною самооцінкою, стійкими навичками самоорганізації й самоуправління, формуванням професійної компетентності; пошуком особистісного почерку у створенні власних моделей майбутньої професійно-педагогічної діяльності.

Стадія стійкого саморозвитку характеризується високим рівнем самоорганізації та самоуправління, самоаналізом і корекцією навчально-професійних досягнень, актуалізацією потреби в подальшому саморозвитку, активним формуванням суб'єктності майбутнього вчителя фізичної культури.

Отже, сформульовано такі основні положення концепції професійної підготовки майбутніх учителів фізичної культури: іiї ядро утворюють взаємопов'язані властивості (релевантність професійному середовищу, інноваційність, комунікативність, трансформованість, комфортність, демократизація i випереджувальний розвиток) i принципи (суб'єктності, неперервності, гуманізації, інтеграції, відкритості й динамічності, науковості, міждисциплінарності, індивідуалізації, проблемності, інноваційності, інтерактивності, креативності, самостійності, рефлективності). Професійна підготовка майбутніх учителів фізичної культури проходить етапи адаптації, диференціації, індивідуалізації та стійкого саморозвитку.

У перспективі плануємо дослідити концептуальні підходи до професійної підготовки майбутніх учителів фізичної культури в контексті сучасних тенденцій вищої фізкультурної освіти.

\section{Література}

1. Буштрук В. Д. Физическая культура и её формирование в процессе высшего профессионального образования : [учеб. пособ.] / В. Ф. Костюченко, Е. Г. Шубин. - СПб. : ГУАП, 2003. - 45 с. 2. Мартиненко В. В. Проблеми неперервної професійної підготовки фахівців фізичного виховання і спорту / В. В. Мартиненко // Педагогіка, психологія та медико-біологічні проблеми фізичного виховання і спорту. - 2006. - № 3. - С. 55-58.

\section{СТРАТЕГІЧНА КОМПЕТЕНТНІСТЬ МАЙБУТНІХ ІНЖЕНЕРІВ У КОНТЕКСТІ СУЧАСНИХ ПРОБЛЕМ НАВЧАННЯ ІНОЗЕМНОЇ МОВИ ПРОФЕСІЙНОГО СПІЛКУВАННЯ}

Бондар Л. В. Стратегічна компетентність майбутніх інженерів у контексті сучасних проблем навчання іноземної мови професійного спілкування.

У статті розглянуто передумови формування стратегічної компетентності студентів технічних спеціальностей у процесі навчання французького професійно спрямованого монологічного мовлення. 3'ясовано, що процес оволодіння мовою професійного спілкування пов'язаний з психо- та лінгвокогнітивними особливостями, 